\author{
Jurnal Litbang: \\ Media Informasi Penelitian, Pengembangan dan IPTEK \\ http://ejurnal-litbang.patikab.go.id \\ Vol. XV No. 2 Desember 2019 Hal 91-106
}

\title{
CAPAIAN PROGRAM PENGEMBANGAN SAPI POTONG DI KABUPATEN WONOGIRI DAN KABUPATEN PATI
}

\section{THE OUTCOME OF CATTLE FARMING DEVELOPMENT PROGRAM IN WONOGIRI REGENCY AND PATI REGENCY}

\author{
Lilyk Eka Suranny 1) a), Arieyanti Dwi Astuti 2) b), Herna Octivia Damayanti 2) b) \\ 1)Badan Perencanaan Pembangunan Daerah dan Penelitian Pengembangan Kabupaten Wonogiri \\ a)Jl. Pemuda I No. 26 Wonogiri. 57612. Jawa Tengah \\ 2)Badan Perencanaan Pembangunan Daerah Kabupaten Pati \\ b)Jl. Raya Pati-Kudus Km. 4 Pati. 59163. Jawa Tengah
}

Naskah Masuk: 9 September 2019 Naskah Revisi: 30 September 2019 Naskah Diterima: 23 Oktober 2019

\begin{abstract}
Cattle becomes the greatest meat producer among ruminants. Both Wonogiri Regency and Pati Regency are the centers of cattle farming in Central Java. This study aims to (1) investigate the development of cattle farming, (2) analyze the performance of the local government in developing cattle farming, (3) describe the differences between Wonogiri Regency and Pati Regency in managing the cattle farming business. This research uses a descriptive method. This research is located in Wonogiri Regency and Pati regency. The data used are secondary data obtained from Statistics Bereau (BPS) of Central Java Province, Wonogiri and Pati regencies, Agriculture Agency of Pati Regency, Fisheries, Marine and Livestockagency of Wonogiri regency. Data are analysed through a descriptive analysis. The results of the study are (1) Cattle farming in Wonogiri Regency and Pati Regency is still traditionally and simply by utilizing agricultural waste as feed, (2) there are 4 animal husbandry carried out by the government of Wonogiri Regency and Pati Regency, in general the performance of each program is achieved even though there is a small portion of indicators that have not yet been achieved, (3) Wonogiri Regency starts to apply communal management, while in Pati Regency, cattle farming is still managed individually.
\end{abstract}

Keywords: beef cattle, development program, livestock

\begin{abstract}
ABSTRAK
Kabupaten Wonogiri dan Pati adalah sentra penghasil ternak sapi potong sebagai salah satu kontributor terbesar penghasil daging. Tujuan penelitian: (1) mengetahui kondisi pengembangan usaha budi daya sapi potong, (2) menganalisis kinerja program pemerintah daerah di bidang peternakan untuk pengembangan sapi potong, (3) menggambarkan perbedaan pengelolaan usaha beternak sapi potong. Penelitian menggunakan metode deskriptif. Lokasi penelitian di Kabupaten Wonogiri dan Kabupaten Pati. Data sekunder diperoleh dari BPS Provinsi Jawa Tengah, BPS Kabupaten Wonogiri dan Kabupaten Pati, Dinas Pertanian Kabupaten Pati, Dinas Perikanan dan Kelautan dan Peternakan Kabupaten Wonogiri. Analisis data menggunakan analisis deskriptif. Hasil penelitian yaitu (1) budi daya sapi potong oleh peternak di Kabupaten Wonogiri dan Kabupaten Pati masih dilakukan secara tradisional dan sederhana dengan memanfaatkan limbah pertanian sebagai pakan ternak sapi potong; (2) terdapat 4 program kerja di bidang peternakan yang dilakukan pemerintah Kabupaten Wonogiri dan Kabupaten Pati, secara umum kinerja setiap program tercapai walaupun ada beberapa indikator yang belum tercapai; (3) terdapat perbedaan pola budi daya sapi potong di Kabupaten Wonogiri dan Kabupaten Pati, yaitu Kabupaten Wonogiri mulai menerapkan pengelololaan secara komunal, sedangkan di Kabupaten Pati pengelolaan masih bersifat individual.
\end{abstract}

Kata kunci: sapi potong, program pengembangan, peternakan

\section{PENDAHULUAN}

Salah satu agenda prioritas yang termuat dalam Nawacita adalah mengarahkan pembangunan pertanian untuk mewujudkan kedaulatan pangan, agar bangsa Indonesia mampu mengatur dan memenuhi kebutuhan pangan secara berdaulat. Sasaran Strategis Kementerian Pertanian tahun 2015-2019 adalah (1) pencapaian swasembada padi, jagung, dan kedelai serta peningkatan produksi gula dan daging; 
(2) peningkatan diversifikasi pangan; (3) peningkatan komoditas bernilai tambah dan berdaya saing dalam memenuhi pasar ekspor dan substansi impor; (4) penyediaan bahan baku bioindustri dan bioenergi; (5) peningkatan pendapatan petani, serta akuntabilitas kinerja aparatur pemerintah yang baik (Renstra Kementerian Pertanian RI Tahun 2015).

Subsektor peternakan merupakan bagian dari sektor pertanian yang berkontribusi dalam penyediaan bahan pangan dari hewan dan usaha industri. Selain itu, subsektor peternakan juga berperan dalam pengentasan kemiskinan, peningkatan kesejahteraan masyarakat dan percepatan pembangunan daerah melalui penyediaan lapangan kerja. Salah satu komoditas hewan ternak yang berkontribusi besar dalam penyediaan bahan pangan yaitu sapi potong. Sapi potong berkontribusi besar sebagai penghasil daging untuk pemenuhan kebutuhan pangan baik lokal, regional maupun nasional serta meningkatkan pendapatan peternak. Permintaan daging sapi setiap tahunnya cenderung meningkat. Hal ini terjadi karena adanya peningkatan jumlah penduduk dan kesadaran masyarakat akan pemenuhan gizi keluarga.

Berdasarkan potensi sumber daya alam, sumber daya genetik, teknologi, dan budaya masyarakat Indonesia, potensi pengembangan ternak sapi sangat potensial di Indonesia (Nuhung, 2015). Produksi daging sapi nasional pada tahun 2017 mencapai 532 ribu ton (Kementerian Pertanian, 2018). Salah satu wilayah yang memberikan kontribusi besar dalam peningkatan produksi daging sapi nasional adalah Provinsi Jawa Tengah yang memiliki potensi besar dalam pengembangan ternak sapi potong dan merupakan sentra penghasil ternak sapi potong terbesar ketiga di Indonesia. Jawa Tengah menyumbang sekitar $11 \%$ produksi daging sapi nasional. Sapi potong merupakan komoditas unggulan subsektor peternakan di Provinsi Jawa Tengah (DRD Jateng, 2010). Komoditas sapi potong dijadikan sebagai entry point percepatan pemberdayaan ekonomi daerah di Jawa Tengah.
Kabupaten Wonogiri dan Kabupaten Pati merupakan wilayah yang menjadi sentra pengembangan sapi potong di Provinsi Jawa Tengah. Pemerintah Provinsi Jawa Tengah telah menyusun konsep pengembangan kawasan komoditas strategis sapi potong di tahun 2013 dan menetapkan 21 kabupaten termasuk Kabupaten Pati dan Kabupaten Wonogiri sebagai wilayah pengembangan, yang mengacu pada Permentan Nomor 50 Tahun 2012 (Susanti dkk., 2014). Pengembangan komoditas sapi potong berdasarkan perwilayahan tersebut merupakan salah satu upaya untuk meningkatkan peran sapi potong dalam perekonomian wilayah antara lain melalui peningkatan populasi dan produksi ternak. Kabupaten Wonogiri dan Kabupaten Pati memiliki daya dukung lingkungan dan sumber daya manusia yang baik dalam pengembangan ternak sapi potong. Sebagian besar mata pencaharian masyarakatnya yaitu sebagai petani peternak.

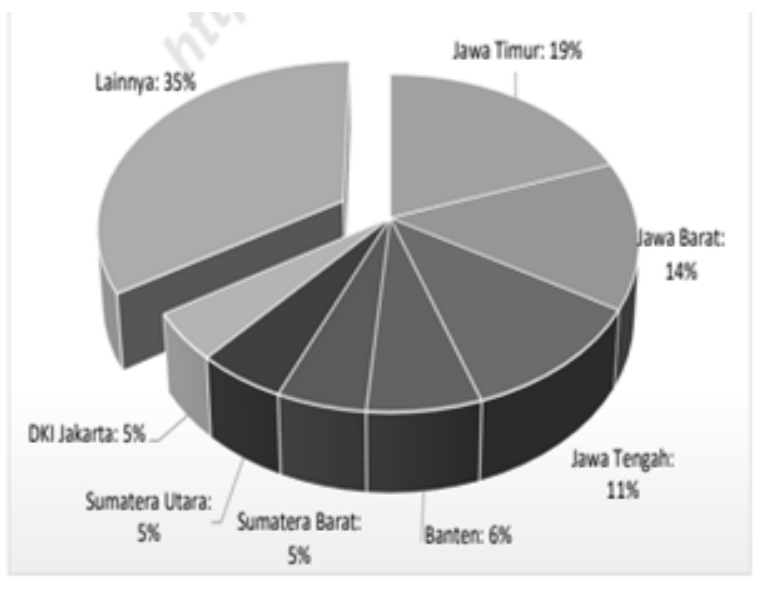

Gambar 1.

Sentra Produksi Daging Sapi Di Indonesia Tahun 2017

Peternakan yang dikelola masyarakat umumnya merupakan peternakan rakyat dengan teknologi budi daya yang masih sederhana. Tujuan pemeliharaan sapi yang dilakukan pada masyarakat perdesaan adalah menjadikan sapi sebagai tabungan yang sewaktu-waktu dapat dijual dan kepemilikan sapi potong dapat meningkatkan status sosial dalam masyarakat. Hal tersebut menjadikan pemeliharaan sapi 
potong dapat meningkatkan status sosial dalam masyarakat. Pada pemenuhan produktivitas daging dan peningkatan ekonomi. Hal ini sesuai dengan ciri peternakan rakyat yang disampaikan Kariyasa dalam Suranny (2017) bahwa ciri peternakan rakyat memiliki skala usaha yang relatif kecil/usaha rumah tangga, merupakan usaha sampingan, menggunakan teknologi sederhana, dan tujuan kepemilikan ternak sebagai tabungan. Tingkat pendidikan petani yang relatif rendah menyebabkan kurangnya pengetahuan budi daya ternak yang baik dan kurangnya adopsi inovasi baru dalam rangka meningkatkan produktivitas usahanya. Beberapa permasalahan tersebut menjadi penghambat dalam upaya pengembangan sapi potong di daerah.

Dalam rangka pengembangan komoditas sapi potong di Kabupaten Wonogiri dan Kabupaten Pati maka perlu adanya strategi dan upaya yang termuat dalam program kerja dari pemerintah daerah. Program kerja pemerintah daerah seharusnya senantiasa bersinergi dengan program kerja pemerintah pusat. Beberapa permasalahan umum berkaitan dengan pengembangan sapi potong di perdesaan seharusnya menjadi target dalam program kerja pada subsektor peternakan. Apabila target program kerja yang dilakukan pemerintah daerah dapat terealisasi maka peningkatan komoditas sapi potong tersebut dapat berperan dalam peningkatan pendapatan masyarakat. Sapi potong nantinya mampu menjadi komoditas unggulan daerah yang mampu meningkatkan PDRB pada subsektor peternakan.

Berdasarkan latar belakang tersebut maka tujuan penelitian ini adalah (1) mengetahui kondisi pengembangan usaha budi daya sapi potong di Kabupaten Wonogiri dan Kabupaten Pati; (2) menganalisis capaian program kerja yang dilakukan pemerintah daerah Kabupaten Wonogiri dan Kabupaten Pati di bidang peternakan dalam rangka pengembangan sapi potong; dan (3) menggambarkan perbedaan pengelolaan usaha beternak sapi potong di Kabupaten Wonogiri dan Kabupaten Pati.

\section{TINIAUAN PUSTAKA}

\section{Sapi Potong}

Menurut Salim (2013) sapi potong merupakan jenis sapi yang dipelihara dengan tujuan utama sebagai penghasil daging, atau sering disebut dengan sapi pedaging. Ciri-ciri sapi pedaging adalah memiliki tubuh yang besar, laju pertumbuhan cepat, jumlah karkas tinggi, dan kualitas daging yang baik. Sapi potong menjadi ternak unggulan karena merupakan hewan yang dapat menopang kebutuhan konsumsi daging. Sapi dapat diternakkan secara sederhana dan mudah, disukai berbagai kalangan dan memiliki postur tubuh yang lebih besar dari pada ternak lainnya. Terdapat beberapa pertimbangan perlunya mengembangkan usaha ternak sapi potong, yaitu 1) relatif tidak tergantung pada ketersediaan lahan dan tenaga kerja yang berkualitas tinggi; 2) memiliki kelenturan bisnis dan teknologi yang luas dan luwes; dan 3) dapat membuka lapangan pekerjaan (Yulianto \& Saparinto, 2010).

Program produksi sapi potong meliputi pembibitan untuk produksi anak (cow calf), pembesaran anak sapi sapihan (growing stocker), serta penggemukan (finisher) Pengembangan usaha pembibitan dan penggemukan sapi potong adalah upaya untuk meningkatkan populasi dan produksi sapi potong untuk memacu ketersediaan daging sapi nasional (Salim, 2013).

\section{Program Pembangunan Peternakan}

Pembangunan peternakan dihadapkan pada sejumlah tantangan baik dari dalam negeri maupun global. Tantangan dari dalam negeri berkaitan dengan dinamika permintaan produk, penyediaan bibit, kualitas bibit, wabah penyakit, dan tuntutan perubahan manajemen usaha. Tantangan global berupa perubahan iklim, krisis pangan dan energi, dan harga pangan dan energi yang terus meningkat (Otoluwa dkk., 2016).

Pembangunan peternakan ditujukan untuk meningkatkan produksi hasil ternak yang sekaligus meningkatkan pendapatan peternak, 
menciptakan lapangan pekerjaan serta meningkatkan populasi dan mutu genetik ternak. Bahri \& Tiesnamurti (2012) menyatakan bahwa tujuan khusus pembangunan peternakan adalah (1) meningkatkan kuantitas dan kualitas bibit ternak; (2) mengembangkan usaha budi daya untuk meningkatkan populasi, produktivitas, dan produksi ternak; (3) meningkatkan dan mempertahankan status kesehatan hewan; (4) meningkatkan jaminan keamanan pangan hewani yang ASUH (Aman, Sehat, Utuh, dan Halal); dan (5) meningkatkan pelayanan prima pada masyarakat di bidang peternakan.

Upaya pengembangan sapi potong dilakukan bersama oleh pemerintah, masyarakat, dan swasta. Pemerintah menetapkan aturan main, memfasilitasi serta mengawasi aliran ketersediaan produk baik jumlah maupun mutu. Swasta dan masyarakat berperan dalam mewujudkan kecukupan produk peternakan (Mayulu dkk., 2010). Program pengembangan sapi potong dapat dilakukan melalui ekstensifikasi dan intensifikasi. Salah satu upaya pengembangan dengan intensifikasi adalah Inseminasi Buatan (IB). Namun demikian, menurut Nuhung (2015) program pembangunan peternakan sapi melalui sistem Inseminasi Buatan (IB) belum mencapai jangkauan yang luas dan masih terbatas, serta tingkat keberhasilannya masih rendah yaitu kurang dari $50 \%$.

Pengembangan sapi potong melalui ekstensifikasi menitikberatkan pada peningkatan populasi ternak dengan didukung pengadaaan dan peningkatan mutu bibit, penanggulangan penyakit, penyuluhan dan pembinaan usaha, bantuan perkreditan, pengadaan serta peningkatan mutu pakan, dan pemasaran. Penelitian Amir (2017) mengutip pernyataan Mubyarto menyebutkan bahwa penyuluhan dan pembinaan terhadap petani-peternak dilakukan untuk mengubah cara beternak dari pola tradisional menjadi usaha ternak komersial dengan menerapkan cara-cara zooteknik yang baik. Zooteknik termasuk saptausaha beternak sapi potong, yang meliputi penggunaan bibit unggul, perkandangan yang sehat, penyediaan dan pemberian pakan yang cukup nutrien, pengendalian terhadap penyakit, pengelolaan reproduksi, pengelolaan pascapanen, dan pemasaran hasil yang baik

Inovasi terkait peningkatan produksi dan produktivitas peternakan telah dilakukan, diantaranya melalui proses genetik yakni pemanfaatan proses biologis melalui rekayasa genetik maupun rekayasa proses untuk menghasilkan ternak dan produk peternakan yang berkualitas. Menurut Said (2015), aplikasi bioteknologi yang telah diterapkan di peternakan di Indonesia, antara lain: bioteknologi reproduksi dan genetik (pemuliaan ternak, inseminasi buatan, transfer embrio, mikromanupulasi embrio yang mencakup rekayasa proses dan rekayasa genetik/transgenetics), bioteknologi pakan (pakan hijauan, konsentrat, dan prebiotik), bioteknologi kesehatan hewan (vaksin, sera, diagnostik, antibiotik, dan hormon), maupun bioteknologi produk-produk ternak (pengolahan daging, kulit, dan teknologi proses).

Salah satu upaya peningkatan nilai tambah usaha peternakan juga bisa dilakukan melalui pemanfaatan limbah peternakan. Namun di sisi lain masyarakat masih belum tertarik untuk mencoba dan mengaplikasikannya. Oleh karena itu, perlu adanya strategi dalam rangka meningkatkan pemanfaatan limbah kotoran sapi pada masyarakat. Menurut Hermain (2014), strategi pemanfaatan kotoran sapi sebagai bahan baku pengembangan pupuk organik dan biogas dapat dilakukan dengan cara sebagai berikut: 1) memperbanyak produksi biogas, pupuk organik cair dan pupuk organik padat dengan cara mengajak peran serta peternak kecil yang letaknya tersebar di wilayah Kabupaten Pati, serta menggunakan sendiri produk pupuk organik tersebut, serta menawarkan pada petani terdekat sebagai pengganti pupuk kimia; 2) pemerintah, swasta dan masyarakat bersama-sama untuk selalu mencari inovasi kesempurnaan proses, peralatan bahan murah dan berbentuk kecil sehingga mudah diaplikasikan dan dicontoh; 3) dukungan pemerintah berupa bimbingan dan dana pengadaan alat serta pemberian insentif perlu diberikan kepada pengguna biogas dan pupuk organik. 


\section{Pengembangan Sapi Potong}

Prospek pengembangan usaha beternak sapi potong untuk memenuhi kebutuhan daging memerlukan adanya manajemen pemeliharaan, pengendalian penyakit, cara perkawinan melalui Inseminasi Buatan (IB), ternak pejantan impor, memperbanyak bibit, memperbanyak anakan, pembesaran pejantan dan betina produktif (Rusdiana dkk., 2016). Menurut Priyanto (2011), pengembangan sapi potong memerlukan pengelompokan berbasis wilayah yang disesuaikan dengan daya dukung. Pola usaha umumnya berupa penggemukan, pembibitan dengan pola intensif dengan fokus pada industri hilir.

Sapi potong dijadikan ternak unggulan karena merupakan penopang konsumsi daging di masyarakat. Keberhasilan suatu usaha penggemukan sapi potong ditentukan oleh ketersediaan bibit unggul, manajemen, serta pakan. Pada umumnya setiap bangsa sapi memiliki sifat genetik yang berbeda, baik dalam produksi daging maupun kemampuan dalam beradaptasi terhadap lingkungan sekitarnya (Salim, 2013).

Pakan memiliki peranan penting dalam perkembangan ternak ruminansia untuk memenuhi kebutuhan pertumbuhan maupun produksi sebagai sumber tenaga. Salim (2013) menyatakan pakan merupakan variabel biaya produksi terbesar dalam usaha peternakan sapi yang mencapai $60-70 \%$ dari total biaya produksi. Pakan ternak ruminansia terdiri dari pakan hijauan dan pakan konsentrat. Ketidaksesuaian pemberian pakan menurut persyaratan kuantitas dan kualitas menyebabkan produktivitas yang dihasilkan akan rendah meskipun ternak memiliki potensi genetik yang tinggi.

\section{Permasalahan Pengembangan Sapi Potong}

Beberapa permasalahan yang dihadapi dalam upaya pengembangan peternakan sapi potong yaitu: (1) pemilik modal kurang tertarik untuk mengembangkan usaha bakalan (calfcow operation), karena secara ekonomis kurang menguntungkan dan waktu pemeliharaan yang relatif lama; (2) keterbatasan ketersediaan pejantan unggul pada usaha pembibitan dan peternakan sapi potong; (3) ketersediaan dan kualitas pakan rendah terutama saat musim kemarau; (4) pemanfaatan limbah pertanian dan agroindustri pertanian belum optimal untuk bahan pakan sapi potong; (5) efisiensi produksi rendah dengan jarak beranak atau calving interval yang panjang; (6) keterbatasan sumber pakan dan masalah potensi genetik belum dapat diatasi secara optimal; dan (7) wabah penyakit (Suryana, 2009).

Nuhung (2015) dalam penelitiannya menyebutkan bahwa permasalahan yang memperlambat pembangunan peternakan sapi potong baik yang bersifat teknis maupun nonteknis yaitu (1) masih lemahnya dukungan politik dan kebijakan dalam pembangunan industri ternak sapi potong; (2) manajemen pembangunan peternakan sapi bersifat alamiah dan minim inovasi; (3) tingkat validitas data rendah; (4) pola pengembangan yang mengedepankan pengembangan ternak rakyat dan mengurangi peranan peternak semakin besar; (5) karakteristik dan sifat usaha beternak sapi rakyat belum komersial; (6) kebutuhan lahan luas untuk pengembangan usaha beternak sapi belum terpenuhi/ keterbatasan lahan; (7) keterbatasan bibit/ bakalan yang bermutu baik atau unggul; dan (8) lemahnya koordinasi antarinstansi, baik pusat dengan daerah maupun pemerintah dengan dunia usaha.

\section{METODE PENELITIAN}

Penelitian ini merupakan penelitian deskriptif yang mengambil lokus di Kabupaten Pati dan Kabupaten Wonogiri. Pemilihan lokasi dilakukan secara purposive, yang mana kedua daerah tersebut memiliki komoditas sapi potong yang dijadikan sebagai komoditas unggulan daerah. Dilihat dari: (1) aspek sumber daya manusia, sebagian besar masyarakat di Kabupaten Wonogiri dan Kabupaten Pati bermata pencaharian sebagai petani sekaligus peternak sapi; (2) aspek sumber daya alam, kedua daerah tersebut memiliki daya dukung 
lahan maupun ketersediaan pakan. Hal ini menjadi penting karena pakan merupakan daya dukung utama dalam usaha peternakan sapi potong. Komoditas sapi potong tersebar di semua kecamatan di Kabupaten Wonogiri dan Kabupaten Pati. Selain itu, dari segi peningkatan populasi, Kabupaten Wonogiri dan Kabupaten Pati tercatat memiliki populasi ternak sapi potong yang jumlahnya relatif meningkat setiap tahunnya.

Data yang digunakan adalah data sekunder yang berasal dari BPS Provinsi Jawa Tengah, BPS Kabupaten Wonogiri dan BPS Kabupaten Pati, Dinas Pertanian Kabupaten Pati, Dinas Perikanan dan Kelautan dan Peternakan Kabupaten Wonogiri. Data yang digunakan adalah data populasi ternak sapi potong di Jawa Tengah tahun 2016-2017, data realisasi pelaksanaan program urusan peternakan (komoditas sapi potong) Kabupaten Wonogiri tahun 2018, realisasi pelaksanaan program urusan peternakan (komoditas sapi potong) Kabupaten Pati tahun 2018, data jumlah populasi sapi potong di Kabupaten Wonogiri dan Kabupaten Pati tahun 2018 dan data penggunaan lahan di Kabupaten Wonogiri dan Kabupaten Pati tahun 2017.

Analisis data menggunakan pendekatan deskriptif. Penelitian ini mendeskripsikan kondisi pengembangan komoditas sapi potong di Kabupaten Wonogiri dan Kabupaten Pati. Kondisi pengembangan yang dimaksud yakni jumlah populasi yang dimiliki, potensi daya dukung lahan yang dimiliki dan sistem budi daya yang diterapkan dari kedua kabupaten tersebut. Selanjutnya dilakukan analisis capaian program kerja di bidang peternakan yang telah dilakukan dalam rangka pengembangan komoditas peternakan utamanya sapi potong. Terdapat 4 program kerja bidang peternakan yang dilakukan di Kabupaten Wonogiri dan Kabupaten Pati, yakni program pencegahan dan penanggulangan penyakit ternak, program peningkatan produksi hasil peternakan, program peningkatan pemasaran hasil peternakan, dan program peningkatan penerapan teknologi peternakan.

\section{HASIL DAN PEMBAHASAN}

\section{Deskripsi Pengembangan sapi potong}

Kabupaten Wonogiri dan Kabupaten Pati merupakan sentra komoditas sapi potong di Provinsi Jawa Tengah. Pada skala Provinsi Jawa Tengah, tahun 2016 Kabupaten Wonogiri menduduki peringkat ketiga dan Kabupaten Pati menduduki peringkat keenam dengan populasi sapi potong terbesar di Jawa Tengah. Secara berurutan kabupaten/kota di Jawa Tengah dengan populasi sapi potong terbesar tahun 2016 yaitu Kabupaten Blora, Kabupaten Grobogan, Kabupaten Wonogiri, Kabupaten Rembang, Kabupaten Boyolali dan Kabupaten Pati. Populasi sapi potong tertinggi Tahun 2017 yaitu Kabupaten Blora, Kabupaten Grobogan, Kabupaten Wonogiri, Kabupaten Rembang, Kabupaten Pati dan Kabupaten Klaten. Jumlah populasi sapi potong di Kabupaten Wonogiri dan Kabupaten Pati mengalami peningkatan. Tercatat jumlah populasi sapi potong di Kabupaten Wonogiri pada tahun 2016 sebesar 157.936 ekor dan tahun 2017 sebesar 158.818 ekor, meningkat 882 ekor atau 0,56\%. Jumlah populasi sapi potong di Kabupaten Pati, tahun 2016 adalah 94.619 ekor, sementara di tahun 2017 adalah 102.701 ekor, meningkat sebanyak 8.082 ekor atau 7,86\%. Peningkatan jumlah populasi sapi potong tersebut tidak terlepas dari program kerja bidang peternakan yang dilaksanakan. Secara lengkap, populasi ternak sapi potong Provinsi Jawa Tengah menurut kabupaten/kota tahun 2016-2017 ditampilkan pada Tabel 1.

\section{Kabupaten Wonogiri}

Potensi pengembangan ternak sapi potong di Kabupaten Wonogiri dapat dilihat dari potensi sumber daya alam dan potensi sumber daya manusia yang dimiliki. Menurut potensi sumber daya manusia, jumlah penduduk di Kabupaten Wonogiri bahwa usia produktif (15-64 tahun) tahun 2017 adalah 630.897 jiwa atau $66,08 \%$ dari total jumlah penduduk (BPS Kabupaten Wonogiri, 2018). 
Tabel 1.

Populasi Ternak di Provinsi Jawa Tengah Menurut Kabupaten/Kota Tahun 2016-2017

\begin{tabular}{|c|c|c|c|}
\hline \multicolumn{2}{|c|}{ Kabupaten/kota } & \multirow{2}{*}{$\begin{array}{c}\begin{array}{c}\text { Sapi Potong } \\
\text { (ekor) tahun } \\
\mathbf{2 0 1 6}\end{array} \\
16.205\end{array}$} & \multirow{2}{*}{$\begin{array}{r}\begin{array}{r}\text { Sapi Potong } \\
\text { (ekor) tahun } \\
\mathbf{2 0 1 7}\end{array} \\
16.287\end{array}$} \\
\hline 1 & Cilacap & & \\
\hline 2 & Banyumas & 12.805 & 14.361 \\
\hline 3 & Purbalingga & 11.472 & 11.509 \\
\hline 4 & Banjarnegara & 31.194 & 29.057 \\
\hline 5 & Kebumen & 65.583 & 65.712 \\
\hline 6 & Purworejo & 19.476 & 19.631 \\
\hline 7 & Wonosobo & 20.024 & 20.751 \\
\hline 8 & Magelang & 78.248 & 78.286 \\
\hline 9 & Boyolali & 95.651 & 96.066 \\
\hline 10 & Klaten & 93.788 & 97.955 \\
\hline 11 & Sukoharjo & 28.530 & 28.594 \\
\hline 12 & Wonogiri & 157.936 & 158.818 \\
\hline 13 & Karanganyar & 63.144 & 63.716 \\
\hline 14 & Sragen & 87.521 & 89.167 \\
\hline 15 & Grobogan & 187.660 & 185.771 \\
\hline 16 & Blora & 222.718 & 231.045 \\
\hline 17 & Rembang & 130.625 & 132.388 \\
\hline 18 & Pati & 94.619 & 102.071 \\
\hline 19 & Kudus & 9.747 & 9.029 \\
\hline 20 & Jepara & 45.928 & 50.291 \\
\hline 21 & Demak & 4.928 & 5.634 \\
\hline 22 & Semarang & 46.238 & 48.444 \\
\hline 23 & Temanggung & 32.830 & 33.125 \\
\hline 24 & Kendal & 20.523 & 20.634 \\
\hline 25 & Batang & 20.002 & 20.985 \\
\hline 26 & Pekalongan & 22.375 & 22.489 \\
\hline 27 & Pemalang & 9.711 & 9.717 \\
\hline 28 & Tegal & 10.544 & 10.649 \\
\hline 29 & Brebes & 27.542 & 32.262 \\
\hline \multicolumn{4}{|c|}{ Kota/Municipality } \\
\hline 1 & Magelang & 206 & 207 \\
\hline 2 & Surakarta & 570 & 593 \\
\hline 3 & Salatiga & 1.349 & 1.346 \\
\hline 4 & Semarang & 4.505 & 3.848 \\
\hline 5 & Pekalongan & 257 & 267 \\
\hline 6 & Tegal & 65 & 64 \\
\hline & Jawa Tengah & 1.671 .573 & 1.710 .769 \\
\hline
\end{tabular}

Sumber data: Provinsi Jawa Tengah dalam Angka Tahun 2017 dan 2018
Umur peternak merupakan salah satu indikator keberhasilan usaha peternakan, dimana usaha budi daya ternak membutuhkan fisik yang sehat dan kuat. Sebagian besar masyarakatnya bekerja pada sektor pertanian, menjadikan peluang melimpahnya limbah pertanian yang digunakan sebagai pakan ternak. Usaha peternakan sapi potong di Kabupaten Wonogiri umumnya masih didominasi oleh peternakan rakyat dan merupakan usaha sambilan dengan usaha pokok bertani.

Berdasarkan potensi sumber daya alam, potensi peternakan di Kabupaten Wonogiri ditunjukkan dengan ketersediaan pakan yang melimpah dari limbah pertanian maupun hijauan lainnya. Lahan pertanian di Kabupaten Wonogiri tahun 2017 tercatat seluas 221.207 ha yang terdiri dari 32.539 ha lahan sawah dan 88.668 lahan tegal (BPS Kabupaten Wonogiri, 2018).

Teknologi budi daya sapi potong yang dilakukan masyarakat Kabupaten Wonogiri pada umumnya masih tradisional dengan menggunakan teknologi yang sangat sederhana. Sumadi dalam Purnomo dkk. (2017) menyatakan bahwa pemeliharaan peternakan sapi rakyat pada umumnya masih dilaksanakan secara tradisional, belum banyak mendapat sentuhan teknologi, pengelolaan sederhana, serta kurang berwawasan agribisnis. Sapi dipelihara dengan cara dikandangkan dan diberi pakan berupa hijauan dan limbah pertanian. Selain hijauan, ternak sapi juga diberi makanan tambahan/konsentrat. Namun demikian, pemberiannya masih sangat sedikit karena harga konsentrat yang relatif mahal sehingga para peternak tidak mampu untuk membelinya.

Limbah pertanian yang digunakan sebagai pakan sapi umumnya belum diolah dan langsung diberikan sebagai pakan ternak. Limbah pertanian yang tidak diolah memiliki nilai kandungan gizi yang relatif rendah, sehingga berakibat produktivitas ternak relatif kurang. Hal ini sesuai dengan pernyataan Rusnan dkk. (2015), yang menyatakan bahwa produktivitas ternak dipengaruhi oleh $70 \%$ dari faktor lingkungan dan 30\% dari faktor ge- 
netik. Diantara faktor lingkungan tersebut salah satunya adalah aspek pakan yang diberikan, yang mempunyai pengaruh 60\%. Hal ini menunjukkan bahwa walaupun potensi genetik ternak itu tinggi, namun jika kualitas pakannya rendah maka produktivitas yang optimal tidak dapat tercapai (Suranny, 2017). Pemanfaatan limbah pertanian sebagai pakan ternak sangat diperlukan untuk menjamin ketersediaan pakan sepanjang tahun terutama saat terjadi musim kemarau atau pada saat produksi hijauan menurun.

\section{Kabupaten Pati}

Sapi potong memiliki peranan penting dalam perekonomian di Kabupaten Pati. Hal ini ditunjukkan pada peranannya terhadap pemenuhan kebutuhan daging sapi, serta sumbangan terhadap PDRB dan tenaga kerja (Susanti dkk., 2014). Potensi peternakan di Kabupaten Pati tidak jauh berbeda dengan Kabupaten Wonogiri, yaitu dapat dilihat dari potensi sumber daya manusia dan potensi sumber daya alam yang dimiliki. Berdasarkan potensi sumber daya manusia, jumlah penduduk usia produktif di Kabupaten Pati sebesar 68,67\% pada tahun 2017 dan sebagian besar masyarakatnya bekerja pada sektor pertanian.

Dilihat dari potensi sumber daya alam yang dimiliki, dukungan ketersediaan pakan yang melimpah dari limbah pertanian maupun hijauan lainnya relatif cukup banyak dan mampu memenuhi kebutuhan pakan. Tercatat pada tahun 2017, di Kabupaten Pati terdapat 119.613 ha lahan pertanian $(79,55 \%)$ yang terdiri dari 59.299 ha lahan sawah dan 60.314 ha lahan bukan sawah (BPS Kabupaten Pati, 2018), sehingga sangat berpeluang menghasilkan limbah pertanian untuk digunakan sebagai pakan ternak.

Sama halnya dengan di Kabupaten Wonogiri, Kabupaten Pati masih didominasi oleh peternakan rakyat dan merupakan usaha sambilan dengan usaha pokok adalah bertani. Potensi sapi potong sebagai penghasil daging belum dimanfaatkan secara optimal karena masih diusahakan secara tradisional. Menurut Suryana (2009) alasan penting dalam peningkatan populasi sapi potong untuk mencapai swasembada daging antara lain: (1) subsektor peternakan berpotensi sebagai sumber pertumbuhan baru pada sektor pertanian; (2) rumah tangga yang terlibat langsung dalam usaha peternakan terus bertambah; (3) tersebarnya sentra produksi sapi potong di berbagai daerah, sedangkan sentra konsumsi terpusat di perkotaan sehingga mampu menggerakkan perekonomian regional; dan (4) mendukung upaya ketahanan pangan, baik sebagai penyedia bahan pangan maupun sebagai sumber pendapatan yang keduanya berperan meningkatkan ketersediaan dan aksesibilitas pangan. Oleh karenanya, diperlukan optimalisasi beternak sapi potong melalui perbaikan manajemen pemeliharaan.

\section{Realisasi Pelaksanaan Program pada Bidang Peternakan}

Peningkatan populasi ternak sapi potong di Kabupaten Wonogiri dan Kabupaten Pati merupakan kerja keras pemerintah daerah yang tertuang dalam program kerja bidang peternakan. Pencapaian target kinerja tentunya tidak mudah karena kebijakan program dan kegiatan yang disusun harus mampu menjawab permasalahan dasar dan isu strategis bidang peternakan di kedua kabupaten tersebut. Ada 4 program kerja bidang peternakan, yaitu program pencegahan dan penanggulangan penyakit ternak, program peningkatan produksi hasil peternakan, program peningkatan pemasaran hasil peternakan, dan program peningkatan penerapan teknologi peternakan. Dari masingmasing program tersebut memiliki indikator kinerja dalam pengukuran pencapaian program. Indikator kinerja dalam pengukuran dari setiap daerah disesuaikan dengan tujuan dan sasaran kinerja bidang peternakan yang sesuai dengan visi misi yang tertuang dalam RPJMD.

\section{Kabupaten Wonogiri}

Terdapat 3 dari 6 indikator program bidang peternakan Kabupaten Wonogiri yang tercapai di tahun 2018. Adapun program yang mencapai target adalah program pencegahan 
dan penanggulangan penyakit ternak, program peningkatan pemasaran hasil peternakan dan program peningkatan penerapan teknologi hasil peternakan (Tabel 2).

Kegiatan yang dilakukan pada program pencegahan dan penanggulangan penyakit ternak yakni kegiatan pelayanan pemeriksaan dan pengobatan ternak dan fasilitasi Asuransi Usaha Ternak Sapi (AUTS). Pada indikator pencegahan dan penanggulangan penyakit ternak, dari target 920 dapat terealisasi 1.338 ekor. Sedangkan pada indikator terlaksananya sosialisasi, pembinaan dan monitoring program AUTS dari target 1.000 ekor sapi yang diasuransikan hanya mampu mencapai 929 ekor. Kegiatan AUTS ini diharapkan dapat memberikan perlindungan jika terjadi sapi mati akibat penyakit, beranak, dan kecelakaan dengan mengalihkan kepada pihak lain melalui pertanggungan asuransi, serta memberikan pendidikan kepada peternak dalam mengelola risiko dan sistem usaha peternakan yang baik (Prayoga dkk., 2018). Hewan ternak yang dapat diasuransikan adalah ternak sapi karena usaha pembibitan dan budi daya sapi memiliki risiko tinggi dan rentan terhadap serangan penyakit dan kematian. Selain itu, kebutuhan masyarakat di tingkat lokal dan nasional pada daging sapi semakin besar seiring dengan pertambahan jumlah penduduk.

Program lain yang realisasinya dapat tercapai sesuai dengan target yang ditetapkan yaitu program peningkatan pemasaran hasil peternakan dengan indikator kinerja jumlah publikasi data informasi harga hasil peternakan. Realisasi yang dihasilkan berupa adanya 9 data publikasi yang didapatkan dari hasil koordinasi dan kerjasama para penyuluh peternakan. Ketersediaan data dan informasi merupakan komponen penting dalam proses penyelenggaraan pembangunan karena mendukung pengambilan kebijakan atau keputusan. Selain itu, data publikasi dapat digunakan sebagai alat kontrol untuk mencegah potensi terjadinya kesalahan serta mendukung penyelenggaraan tata kelola pemerintahan yang transparan, akuntabel dan partisipatif (Kementerian Pertanian, 2018).

Tabel 2.

Realisasi Pelaksanaan Program Urusan Peternakan (Komoditas Sapi Potong) Kabupaten Wonogiri Tahun 2018

\begin{tabular}{|c|c|c|c|c|c|c|}
\hline No & Program & Satuan & Indikator Kinerja & Target & Realisasi & $\begin{array}{c}\text { Pencapaian } \\
\text { Program }\end{array}$ \\
\hline \multirow[b]{2}{*}{1} & \multirow{2}{*}{$\begin{array}{l}\text { Pencegahan dan } \\
\text { penanggulangan } \\
\text { penyakit ternak }\end{array}$} & \multirow[b]{2}{*}{ Ekor } & $\begin{array}{l}\text { Pencegahan dan } \\
\text { penanggulangan } \\
\text { penyakit ternak }\end{array}$ & 920 & 1.338 & Tercapai \\
\hline & & & $\begin{array}{l}\text { Terlaksananya } \\
\text { sosialisasi, pembinaan } \\
\text { dan monitoring } \\
\text { program AUTS }\end{array}$ & 1.000 & 929 & $\begin{array}{c}\text { Tidak } \\
\text { Tercapai }\end{array}$ \\
\hline 2 & $\begin{array}{l}\text { Peningkatan } \\
\text { produksi hasil } \\
\text { peternakan }\end{array}$ & Ekor & $\begin{array}{l}\text { Peningkatan populasi } \\
\text { ternak unggulan }\end{array}$ & 160.882 & 159.446 & $\begin{array}{l}\text { Tidak } \\
\text { tercapai }\end{array}$ \\
\hline 3 & $\begin{array}{l}\text { Peningkatan } \\
\text { pemasaran hasil } \\
\text { peternakan }\end{array}$ & $\begin{array}{c}\text { Data harga } \\
\text { pasar } \\
\text { komoditas }\end{array}$ & $\begin{array}{l}\text { Publikasi data } \\
\text { informasi harga hasil } \\
\text { peternakan }\end{array}$ & 9 & 9 & Tercapai \\
\hline \multirow{2}{*}{4} & $\begin{array}{l}\text { Peningkatan } \\
\text { penerapan }\end{array}$ & Ekor & $\begin{array}{l}\text { Peningkatan populasi } \\
\text { sapi potong hasil IB }\end{array}$ & 42.500 & 41.882 & $\begin{array}{c}\text { Tidak } \\
\text { Tercapai }\end{array}$ \\
\hline & $\begin{array}{l}\text { teknologi } \\
\text { peternakan }\end{array}$ & $\begin{array}{l}\text { Kelompok } \\
\text { ternak }\end{array}$ & $\begin{array}{l}\text { Peningkatan tertib } \\
\text { pengelolaan ternak }\end{array}$ & 60 & 81 & Tercapai \\
\hline
\end{tabular}

Sumber: Dinas Perikanan dan Kelautan dan Peternakan Kabupaten Wonogiri Tahun 2018 
Program selanjutnya yang mencapai target adalah Peningkatan penerapan teknologi peternakan. Kelompok ternak yang berhasil terealisasi berjumlah 81 kelompok ternak dari target 6 kelompok ternak. Kelompok ternak diharapkan dapat meningkatkan sistem pengelolaan budi daya ternaknya dengan menerapkan teknologi di bidang peternakan (khususnya sapi potong). Tujuan penerapan teknologi adalah untuk efisiensi usaha, peningkatan kualitas dan kuantitas ternak sapi potong.

Namun demikian, pada program peningkatan hasil peternakan dengan indikator peningkatan populasi ternak realisasinya tidak tercapai sesuai target yang ditetapkan, walaupun jumlah populasi ternak ternak sapi potong meningkat dari tahun sebelumnya. Berdasarkan data dari Dinas Perikanan dan Kelautan dan Peternakan Kabupaten Wonogiri, tercatat pada tahun 2017 jumlah populasi sapi potong di Kabupaten Wonogiri tahun 2017 sebesar 158.818 ekor dan tahun 2018 sebesar 159.446 ekor, meningkat 628 ekor. Sasaran dan indikator kinerja meningkatnya populasi ternak unggulan tidak dapat tercapai karena telah dua tahun di Kabupaten Wonogiri tidak melakukan pengembangan ternak dengan bantuan/hibah, yang disebabkan adanya regulasi penerima bantuan/hibah. Pengembangan dengan pola swadaya yang dilakukan ternyata belum dapat memenuhi target. Usaha peternakan sapi potong membutuhkan modal yang besar, baik dari penyediaan bibit dan pakan sehingga hanya beberapa orang saja yang mampu untuk mengembangkan usahanya. Modal merupakan kendala utama yang dihadapi peternak di perdesaan. Pada umumnya, peternak di perdesaan belum mampu mengakses sumber pembiayaan untuk peningkatan modal usaha.

Indikator kinerja program peningkatan penerapan teknologi peternakan yang tidak mencapai target adalah peningkatan populasi sapi potong hasil Inseminasi Buatan (IB). Jumlah sapi potong hasil IB di tahun 2018 sebanyak 41.882 ekor, sementara target sapi potong hasil IB di tahun tersebut adalah 42.500 ekor. Kondisi tersebut kemungkinan me- nyebabkan target peningkatan populasi sapi potong di Kabupaten Wonogiri tidak sesuai dengan target yang diharapkan. Keberhasilan IB ditentukan oleh beberapa faktor, seperti kualitas umum straw (semen), kondisi resepien, deteksi berahi pada sapi, dan keterampilan inseminator (Arman \& Fattah, 2017). Penyebab tidak tercapainya target IB sapi potong di Kabupaten Wonogiri, diantaranya kurangnya akurasi deteksi berahi oleh peternak dan juga kesehatan ternak sapi betina. Pengetahuan peternak yang kurang mengenai IB karena sebagian besar peternak berpendidikan rendah sehingga adopsi pengetahuan tentang IB kurang.

Alternatif solusi pengembangan sapi potong diantaranya dengan pengelompokan wilayah berdasarkan potensinya. Berdasarkan Susanti dkk. (2014), potensi wilayah yang perlu diperhatikan untuk pengembangan sapi potong, yaitu (1) sumber pakan hijau, disesuaikan dengan daya dukung ketersediaan pakan hijauan; (2) wilayah basis, dengan adanya sistem perwilayahan komoditas diharapkan dapat meningkatkan efisiensi sistem produksi dan distribusi; dan (3) hierarki wilayah berdasarkan tingkat kapasitas pelayanan pendukung, dimana kapasitas pelayanan pendukung ini berkaitan erat dengan sebaran populasi, pemerataan, dan efisiensi jangkauan. Pendapat tersebut didukung oleh Ahmad \& Sugiharto (2014) yang menyatakan bahwa pengembangan sapi potong berdasarkan (1) potensi pakan hijauan; jaminan ketersediaan pakan untuk sapi potong (2) infrastruktur, meliputi ketersediaan pabrik pakan ternak, ketersediaan pasar hewan dan kondisi transportasi jalan raya; (3) potensi teknis, dukungan sumber daya alam penunjang peternakan sapi potong seperti ketersediaan air; (4) potensi sumber daya manusia, meliputi pengalaman beternak dan tingkat pendidikan; dan (5) potensi sosial, dilihat dari berapa banyak kelompok ternak sapi.

\section{Kabupaten Pati}

Kabupaten Pati memiliki empat program untuk urusan peternakan, dimana terdapat tiga program yang mampu mencapai target yang 
ditetapkan yaitu program pencegahan dan penanggulangan penyakit ternak, program peningkatan produksi hasil peternakan, dan program peningkatan penerapan teknologi peternakan. Capaian program urusan peternakan (komoditas sapi potong) Kabupaten Pati tahun 2018 dapat dilihat pada Tabel 3.

Program pencegahan dan penanggulangan penyakit ternak dengan indikator rasio tenaga paramedis/medis terhadap populasi ternak dengan target 0,070 dapat tercapai 0,073. Kesesuaian jumlah tenaga paramedis/medis terhadap jumlah populasi ternak sangat berpengaruh terhadap peningkatan kesehatan ternak. Jika tenaga medis/paramedis tersedia cukup maka kondisi ternak dapat terpantau dengan baik. Hal ini tentunya juga berpengaruh pada peningkatan jumlah populasi ternak dan produktivitas ternak tersebut.

Program peningkatan produksi hasil peternakan dengan indikator kinerja peningkatan populasi sapi potong, dengan target yang ditetapkan di tahun 2018 sebanyak 104.110 ekor sapi potong dapat terealisasi sebanyak 107.226 ekor sapi potong. Jumlah sapi potong di tahun tersebut meningkat sebanyak 4.526 ekor dari tahun 2017.
Program penerapan teknologi peternakan dengan indikator kinerja peningkatan persentase kelompok ternak yang menerapkan teknologi peternakan, target kinerja yang ditetapkan tahun 2018 yaitu 1,93\% dapat tercapai 1,97\%. Data dari Dinas Pertanian Kabupaten Pati, persentase kelompok ternak yang menerapkan teknologi peternakan di tahun 2017 adalah 1,42\% dan di tahun 2018 adalah 1,97\%. Nilai tersebut meningkat sebesar $0,55 \%$. Semakin banyak kelompok ternak yang mengadopsi teknologi peternakan akan mampu meningkatkan pengelolaan usaha ternak sehingga dapat berpengaruh pada peningkatan produktivitas usaha. Hal inilah yang juga mempengaruhi tercapainya target peningkatan populasi sapi potong di Kabupaten Pati. Selanjutnya, kegiatan yang dilaksanakan pada program penerapan teknologi peternakan diantaranya pelaksanaan IB dan pembinaan pelatihan pada kelompok ternak, diantaranya pelatihan pembuatan pakan ternak fermentasi, pembuatan pupuk organik, dan pengelolaan ternak secara komunal. Inovasi yang diterapkan pada kelompok ternak rata-rata bukan merupakan inovasi yang baru, namun replikasi dari inovasi yang telah dilakukan sebelumnya.

Tabel 3.

Realisasi Pelaksanaan Program Urusan Peternakan (komoditas sapi potong) Kabupaten Pati Tahun 2018

\begin{tabular}{|c|c|c|c|c|c|c|}
\hline No & Program & Satuan & Indikator Kinerja & Target & Realisasi & $\begin{array}{l}\text { Pencapaian } \\
\text { Program }\end{array}$ \\
\hline 1 & $\begin{array}{l}\text { Program } \\
\text { pencegahan dan } \\
\text { penanggulangan } \\
\text { penyakit ternak }\end{array}$ & Rasio & $\begin{array}{l}\text { Rasio tenaga } \\
\text { paramedis/ medis } \\
\text { terhadap populasi } \\
\text { ternak }\end{array}$ & 0,07 & 0,073 & Tercapai \\
\hline 2 & $\begin{array}{l}\text { Program } \\
\text { peningkatan } \\
\text { produksi hasil } \\
\text { peternakan }\end{array}$ & Ekor & $\begin{array}{l}\text { Peningkatan populasi } \\
\text { sapi potong }\end{array}$ & 104.110 & 107.226 & Tercapai \\
\hline 3 & $\begin{array}{l}\text { Program } \\
\text { peningkatan } \\
\text { pemasaran hasil } \\
\text { peternakan }\end{array}$ & Kilogram & $\begin{array}{l}\text { Peningkatan hasil } \\
\text { produksi peternakan }\end{array}$ & 5.754 .550 & 5.250 .773 & Tidak tercapai \\
\hline 4 & $\begin{array}{l}\text { Program } \\
\text { peningkatan } \\
\text { penerapan } \\
\text { teknologi } \\
\text { peternakan }\end{array}$ & $\%$ & $\begin{array}{l}\text { Persentase kelompok } \\
\text { ternak yang } \\
\text { menerapkan teknologi } \\
\text { peternakan }\end{array}$ & 1,93 & 1,97 & Tercapai \\
\hline
\end{tabular}

Sumber: Dinas Perikanan dan Kelautan dan Peternakan Kabupaten Pati Tahun 2018 
Inovasi pengelolaan limbah peternakan tentunya akan dapat meningkatkan nilai tambah usaha ternak yang dilakukan oleh masyarakat. Namun inovasi tersebut ternyata belum mampu menarik masyarakat untuk mengaplikasikannya. Kondisi ini pernah diteliti oleh Hermain (2014) bahwa masyarakat di Desa Bageng, Kecamatan Gembong, Kabupaten Pati memiliki potensi yang besar dalam pemanfaatan limbah kotoran sapi sebagai sumber energi. Sebelumnya masyarakat hanya memanfaatkan kotoran sapi sebagai pupuk kandang untuk Jeruk Pamelo. Potensi kotoran sapi yang dihasilkan di Desa Bageng yaitu 6.193 $\mathrm{kg} /$ hari sampai dengan $8.778 \mathrm{~kg} / \mathrm{hari}$, kotoran sapi tersebut dapat diolah menjadi biogas sebanyak 131,78 $\mathrm{m}^{3} /$ hari-86,79 $\mathrm{m}^{3} /$ hari sekaligus sebagai pupuk organik bagi tanaman Jeruk Pamelo. Pengembangan biogas kotoran sapi mampu meningkatkan perekonomian masyarakat melalui penghematan pembelian LPG dan mampu menghasilkan pupuk organik untuk pertumbuhan Jeruk Pamelo.

Program peningkatan pemasaran hasil peternakan dengan indikator peningkatan hasil produksi peternakan, target yang ditetapkan tidak tercapai yakni dari target pemasaran daging ternak sebesar $5.754 .550 \mathrm{~kg}$ daging ternak, yang didalamnya termasuk daging sapi hanya tercapai $5.250 .773 \mathrm{~kg}$ daging ternak. Penyebab tidak tercapainya target program tersebut adalah permintaan pasar akan daging mengalami penurunan. Permintaan daging pada pasar menurun disebabkan oleh harga daging yang selalu meningkat sementara tingkat pendapatan masyarakat yang rendah menyebabkan terjadinya perubahan pola konsumsi. Hal ini sesuai dengan Sukirno (2003) bahwa beberapa faktor yang mempengaruhi permintaan yaitu ketersediaan barang, konsumsi dan pendapatan masyarakat. Perubahan pendapatan selalu menimbulkan perubahan permintaan berbagai jenis barang. Rasyaf dalam Fatmawati dkk. (2016) menyebutkan bahwa bertambahnya penghasilan akan menyebabkan permintaan barang atau produk bertambah. Perubahan dalam pendapatan juga akan mengakibatkan berkurangnya permintaan komoditas yang akan dibeli terutama oleh rumah tangga yang tetap atau berkurang pendapatannya (Lipsey et al., 1997).

Penelitian Sutrisno dkk. (2015) menyebutkan bahwa faktor-faktor produksi yang mempengaruhi produksi sapi potong di Kabupaten Pati yaitu bibit/bakalan sapi potong, pakan, vitamin, tenaga kerja peternakan, dan modal usaha. Lebih lanjut dijelaskan bahwa usaha beternak sapi potong di Kabupaten Pati menunjukkan prospek yang bagus dan layak dijalankan dengan $\mathrm{R} / \mathrm{C}$ rasio 1,16.

Alternatif solusi yang dapat dilakukan untuk pengembangan usaha beternak sapi potong di Kabupaten Pati adalah pemetaan potensi wilayah, yaitu dengan memperhatikan faktor-faktor produksinya, berupa (1) bibit atau bakalan sapi potong harus berkualitas seperti jenis sapi leumosin, simental, atau sapi lokal agar selama penggemukan pertumbuhannya lebih cepat; (2) sistem perkandangan yang digunakan untuk penggemukan sapi potong perlu diperhatikan, karena masih banyak yang bersifat semi permanen dan tingkat kebersihannya belum optimal; (3) pemberian pakan berkualitas seperti pakan hijauan, limbah pertanian serta penambahan konsentrat sesuai anjuran; (4) pemberian vitamin sesuai anjuran ; (5) pemberian obat, terutama pada sapi potong yang sedang sakit dengan koordinasi dengan petugas kesehatan hewan; (6) penambahan kapasitas dan kualitas SDM tenaga kerja pada usaha beternak sapi potong; dan (7) pinjaman modal dari perbankan dengan persyaratan yang mudah.

Nuhung (2015) dalam penelitiannya menyebutkan strategi untuk mencapai swasembada daging sapi yaitu (1) kebijakan dan kemauan politik, diperlukan kebijakan yang komprehensif dari hulu sampai hilir untuk pengembangan usaha beternak sapi potong; (2) manajemen dan pola pengembangan, perencanaan harus bersifat komprehensif dan tidak parsial, serta mengakomodasi sifat-sifat biologis dan karakteristik ternak sapi potong, budaya peternak, dan persaingan dengan 
daging sapi impor; (3) pola inti plasma, merupakan model pembangunan usaha beternak sapi potong dengan kapasitas produksi lebih besar dan akan menciptakan kesempatan kerja bagi masyarakat; (5) pola peternakan sapi terpadu, merupakan pengintegrasian seluruh subsistem dalam suatu sistem usaha yaitu usaha pembibitan, usaha budi daya dan usaha penggemukan; (6) pola franchise, pelibatan kelompok peternak sapi untuk mendorong peternakan sapi rakyat, dan dengan melibatkan franchise untuk mendorong usaha menengah dan koperasi. Objek franchise pada usaha beternak sapi yaitu bibit/bakalan sapi, teknologi pakan maupun teknologi budi daya, dan pakan.

Usaha beternak sapi potong di Kabupaten Wonogiri dan Kabupaten Pati memiliki banyak persamaan, mulai dari jenis sapi yang diternakkan dan pola usahanya yang masih tradisional. Namun, terdapat perbedaan dari cara budi daya ternak sapi potong yaitu peternak sapi potong di Kabupaten Wonogiri sudah mulai menerapkan pengelolaan secara komunal. Ternak sapi potong disatukan dalam kandang komunal. Hal ini dimaksudkan untuk efisiensi usaha dan mempermudah perawatan dan pengawasan. Untuk peternak sapi potong di Kabupaten Pati pengelolaan masih bersifat individual, dilakukan sendiri oleh rumah tangga peternak sapi.

\section{KESIMPULAN DAN SARAN}

\section{Kesimpulan}

Berdasarkan hasil penelitian diatas, maka dapat disimpulkan sebagai berikut: (1) budi daya sapi potong oleh peternak di Kabupaten Wonogiri dan Kabupaten Pati masih dilakukan secara tradisional dan sederhana dengan memanfaatkan limbah pertanian sebagai pakan ternak sapi potong; (2) terdapat 4 program di bidang peternakan yang dilakukan pemerintah Kabupaten Wonogiri dan Kabupaten Pati, secara umum kinerja setiap program tercapai walaupun ada beberapa indikator yang belum tercapai; dan (3) terdapat perbedaan pola budi daya sapi potong di Kabupaten Wonogiri dan Kabupaten Pati, yaitu Kabupaten Wonogiri mulai menerapkan pengelololaan secara komunal, sedangkan di Kabupaten Pati pengelolaan masih bersifat individual.

\section{Saran}

Secara keseluruhan pemerintah Daerah Kabupaten Wonogiri dan Kabupaten Pati perlu melakukan sosialisasi, pelatihan dan pendampingan tentang budi daya ternak sapi potong terpadu dan terintegrasi, bahkan sampai pada pengelolaan sapi potong secara komunal. Selain itu, pengelolaan limbah hasil peternakan penting dilakukan untuk mencegah pencemaran lingkungan dan dapat meningkatkan nilai tambah usaha peternakan. Kotoran sapi dapat dijadikan sumber energi pengganti gas LPG (biogas) dan sebagai pupuk organik. Perlu juga adanya pengelolaan/ pelatihan kepada Petani/Peternak dalam rangka pengelolaan pakan untuk meminimalisir kekurangan pakan saat musim kemarau, misal pembuatan pakan melalui pengawetan, fermentasi ataupun amoniasi dengan pemanfaatan limbah hasil pertanian. Khusus di

Kabupaten Wonogiri perlu untuk meningkatkan pengetahuan peternak mengenai teknologi IB agar dapat meningkatkan ketercapaian target pada program peningkatan penerapan teknologi peternakan ditahun selanjutnya. Sedangkan di Kabupaten Pati untuk mendukung ketercapaian pada program peningkatan pemasaran hasil peternakan maka perlu adanya upaya penanganan pascapanen hasil usaha peternakan, tidak hanya dijual dalam bentuk daging namun bisa diolah menjadi berbagai jenis olahan sehingga dapat meningkatkan nilai jualnya serta menarik minat beli konsumen. Upaya-upaya tersebut sebaiknya dimasukkan dalam program kerja pemerintah daerah dalam bidang peternakan. Selanjutnya perlu dilakukan evaluasi terhadap upaya tersebut untuk perumusan perbaikan kegiatan di masa yang akan datang. 


\section{DAFTAR PUSTAKA}

Ahmad, A. A., \& Sugiharto, M. (2014). Peta Pengembangan Sapi Potong di Kabupaten Banjarnegara. EKO-REGIONAL, 9(2), 106115.

Amir, S. 2017. Potensi Pengembangan Usaha Ternak Sapi Potong di Desa Balassuka Kecamatan Tombolo Pao Kabupaten Gowa. Skripsi. Makassar: Universitas Islam Negeri Alauddin.

Arman \& Fattah, A. H. (2017). Tingkat Keberhasilan Inseminasi Buatan di Desa Cenrana Kecamatan Kahu Kabupaten Bone. Jurnal Agrominansia, 2(1), 26-35.

Bahri, S., \& Tiesnamurti, B. (2012). Strategi Pembangunan Berkelanjutan dengan Memanfaatkan Sumber Daya Lokal (Strategy on Sustainable Development by Using Local Resources). Journal Penelitian dan Pengembangan Pertanian, 31(4), 142 152.

Badan Pusat Statistik Kabupaten Pati. (2018). Kabupaten Pati dalam Angka Tahun 2017. Pati: BPS Kabupaten Pati.

Badan Puat Statistik Kabupaten Wonogiri. (2018). Kabupaten Wonogiri dalam Angka Tahun 2017. Wonogiri: BPS Kabupaten Wonogiri.

Badan Pusat Statistik Provinsi Jawa Tengah. (2017). Provinsi Jawa Tengah dalam Angka Tahun 2016. Jawa Tengah: BPS Provinsi Jawa Tengah.

Badan Pusat Statistik Provinsi Jawa Tengah. (2018). Provinsi Jawa Tengah dalam Angka Tahun 2017. Jawa Tengah: BPS Provinsi Jawa Tengah.

Fatmawati, Rostin, \& Baso, J. N. 2016. Faktorfaktor yang Mempengaruhi Permintaan Daging Sapi di Indonesia. Jurnal Ekonomi, 1(1), 128-134.

Hermain, T. P. (2015). Pemetaan Potensi Biogas dan Pupuk dari Kotoran Sapi untuk Mendukung Wisata Pamelo Desa Bageng Kecamatan Gembong Kabupaten Pati. Jurnal Litbang: Media Informasi Penelitian, Pengembangan dan IPTEK, 9(2), 103- 112.
Kementerian Pertanian Republik Indonesia. (2015). Rencana Strategis Kementerian Pertanian RI Tahun 2015-2019. Jakarta: Kementerian Pertanian RI.

Kementerian Pertanian Republik Indonesia.

(2018). Statistik Peternakan dan Kesehatan Hewan Tahun 2018. Jakarta: Direktorat Jendral Peternakan dan Kesehatan Hewan.

Lipsey, G., Courant, Purvis, \& Steiner. (1997). Pengantar Ilmu Ekonomi. Edisi Ke-8 Jilid 1. Jakarta: Erlangga.

Mayulu, H., Sunarso, Sutrisno, C. I., Sumarsono. (2010). Kebijakan Pengembangan Peternakan Sapi Potong di Indonesia. Jurnal Litbang Pertanian, 29(1), 34-41.

Nuhung, I. A. (2015). Kinerja, Kendala, dan Strategi Pencapaian Swasembada Daging Sapi. Forum Penelitian Agro Ekonomi, 33 (1), 63-80.

Otoluwa, M. A., Salendu, A. H. S., Rintjap, A. K., \& Massie, M. T. (2016). Prospek Pengembangan Usaha Ternak Sapi Potong di kecamatan Bolangitang Timur Kabupaten Bolaang Mongondow Utara. Jurnal Zootek, 36 (1), 191-197.

Prayoga, I.F., Yennie, A.M.R., \& Siti, N. (2018). Pelaksanaan Program Asuransi Usaha Ternak Sapi. Paktum Law Journal, 3(1), 451462.

Priyanto, D. (2011). Strategi Pengembangan Usaha Ternak Sapi Potong dalam Mendukung Program Swasembada Daging Sapi dan Kerbau Tahun 2014. Jurnal Litbang Pertanian, 30(3), 108-116.

Purnomo, S. H., Endang, T. R., \& Sidiq, B. A. (2017). Strategi Pengembangan Peternakan Sapi Potong Rakyat di Kecamatan Wuryantoro Kabupaten Wonogiri. Buletin Peternakan, 41(4), 484-494.

Rusdiana, S., Adiati, U., \& Hutasoit, R. (2016). Analisis Ekonomi Usaha Ternak Sapi Potong Berbasis Agroekosistem di Indonesia. Jurnal Sosial Ekonomi dan Kebijakan Pertanian, 5(2), 137-149. 
Rusnan, H., Kaunang, \& Yohanis, L. R. T. (2015). Analisis Potensi dan Strategi Pengembangan Sapi Potong Dengan Pola Integrasi Kelapa-Sapi di Kabupaten Halmahera Selatan Provinsi Maluku Utara. Jurnal Zootek, 35 (2), 187 - 200.

Said, S. (2015). Peran Iptek dalam Peningkatan Produktivitas Ternak Lokal. Seminar Nasional Peternakan. Makasar: Universitas Hasanuddin.

Salim. E. (2013). Sukses Bisnis dan Beternak Sapi Potong. Yogyakarta: Andi Publisher.

Sukirno, S. (2003). Pengantar Teori Mikroekonomi. Edisi Ketiga, Jakarta: Grafindo.

Suryana. (2009). Pengembangan Usaha Ternak Sapi Potong Berorientasi Agribisnis Dengan Pola Kemitraan. Jurnal Litbang Pertanian, 28 (1), 29-37.

Susanti, Y., Priyarsono, D. S., \& Mulatsih, S. (2014). Pengembangan Peternakan Sapi Potong untuk Peningkatan Perekonomian Provinsi Jawa Tengah: Suatu Pendekatan Perencanaan Wilayah. Jurnal Agribisnis Indonesia, 2 (2), 177-190.
Suranny, L.E. (2017). Pemberdayaan pada Kelompok Ternak Sapi Potong Berorientasi Agribisnis Pedesaan. Pati: CV. Mitra Sejati.

Yulianto, P., \& Saparinto, C. (2010). Pembesaran Sapi Potong Secara Intensif. Jakarta: Penebar Swadaya.

\section{BIODATA PENULIS}

Lilyk Eka Suranny, lahir 25 September 1986 di Kabupaten Wonogiri Jawa Tengah. Sarjana Sains dari Institut Teknologi Bandung. Saat ini bekerja sebagai Peneliti di Bappeda dan Litbang Kabupaten Wonogiri.

Arieyanti Dwi Astuti, lahir 24 Agustus 1984 di Pati Jawa Tengah. Pendidikan Magister Ilmu Lingkungan Universitas Diponegoro tahun 2018. Saat ini bekerja sebagai Peneliti di Badan Perencanaan Pembangunan Kabupaten Pati.

Herna Octivia Damayanti, lahir 6 Oktober 1985 di Kudus Jawa Tengah. Pendidikan Magister Manajemen Sumber daya Pantai Universitas Diponegoro tahun 2016. Saat ini bekerja sebagai Peneliti di Badan Perencanaan Pembangunan Kabupaten Pati. 
